\title{
POPULATION ASSESSMENT OF BELDING'S YELLOWTHROAT (GEOTHLYPIS BELDINGI) AT SAN IGNACIO OASIS, BAJA CALIFORNIA SUR, MEXICO
}

\author{
ROBERTO CARMONA, GERARDO MARRÓN, SERGIO ÁGUILA, ABIGAIL \\ RIVAS, SERGIO FLORES RAMÍREZ, and HÉCTOR REYES BONILLA, \\ Departamento Académico de Ciencias Marinas y Costeras, Universidad \\ Autónoma de Baja California Sur, A.P. 19-B, La Paz, Baja California Sur, Mexico, \\ 23080; beauty@uabcs.mx
}

\begin{abstract}
Belding's Yellowthroat (Geothlypis beldingi) is an endangered species endemic to the southern half of the Baja California Peninsula. There are no current estimates of the species' population, crucial to scientifically based management for its conservation. Therefore, we assessed the species' population at one of its major sites, the oasis of San Ignacio. During the reproductive season, the density of birds reached around 17 individuals per hectare, representing an estimated total population of about 250 birds. Previous estimates of the abundance of Belding's Yellowthroat are inconsistent, emphasizing the need for a re-evaluation with more robust methods. In addition, we recorded a significant decrease in the number of males of the species immediately after the reproductive season, which suggests that these birds may disperse immediately after the breeding season, possibly to avoid competition with their conspecifics. If so, this has important implications for this bird's spatial population structure.
\end{abstract}

RESUMEN: La Mascarita peninsular (Geothlypis beldingi) es una especie endémica de la península de Baja California, México, que está en peligro de extinción, además no cuenta con estimados poblacionales recientes, por lo que en este trabajo evaluamos la población de uno de los sitios de mayor importancia para la especie, el oasis de San Ignacio. La densidad de aves en la época reproductiva fue de cercana a 17 aves/ha, con lo que el tamaño poblacional estimado para el oasis es de aproximadamente 250 aves. Estimados anteriores de la abundancia de la Mascarita peninsular son inconsistentes, lo que enfatiza la necesidad de una evaluación con métodos más robustos. Adicionalmente, registramos una disminución drástica en el número de machos de la especie inmediatamente después de la época de reproducción, lo que sugiere que estas aves podrían dispersarse después de la temporada de anidación, para evitar la competencia con sus hembras y juveniles, lo cual tendría importantes implicaciones para la estructura espacial de la población.

The Baja California Peninsula is characterized by its aridity. However, scattered freshwater bodies of significant size (i. e., oases) provide attractive habitats for several species of migratory and resident birds, including Belding's Yellowthroat (Geothlypis beldingi), endemic to the peninsula. This species is largely restricted to oases with large patches of Southern Cattail (Typha domingensis), Common Reed (Phragmites australis), or both (Rodríguez-Estrella et al. 1997, 1999, Escalante 2000). BirdLife International (2016) estimated its total population size at between 1500 and 4000 birds. Because of its restricted distribution and small population size, Belding's Yellowthroat has been designated as endangered by the Mexican government (SEMARNAT 2010) and by the International Union for the Conservation of Nature (BirdLife International 2016).

Because of its restricted distribution and its association with emergent 
plants, until recently it was thought that the species' ability to disperse was quite limited. In their study of its habitat preferences, Rodríguez-Estrella et al. (1999) reported that $80 \%$ of their sightings were on cattail or reed. Only $15 \%$ and $5 \%$ were on palms or nearby desert vegetation, respectively, but always within $50 \mathrm{~m}$ of the main water body. Therefore, they inferred that Belding's Yellowthroats are unable to leave the oasis in which they reside. Nevertheless, Erickson et al. (2008) reported Belding's Yellowthroats far from their reproductive areas, pointing to the need for more studies of the species' capability for dispersal.

The restricted distribution, reduced abundance, and limited dispersal ability of Belding's Yellowthroat suggest that the species may comprise nonequilibrium metapopulations. This has major implications for its conservation and management, since non-equilibrium metapopulations consist of demographically independent unconnected subpopulations and are thus prone to extirpation because of their isolation and small size (Stith et al. 1996).

San Ignacio oasis, located within the Vizcaíno Biosphere Reserve in northern Baja California Sur, is recognized as the site of the largest concentration of Belding's Yellowthroat (Rodríguez-Estrella et al. 1999, Erickson et al. 2008). BirdLife International (2000, 2007, cited by Erickson et al. 2008) reported a population estimated at 537 to 648 individuals between November 1994 and August 1996 but did not specify the methods by which the estimate was generated.

Belding's Yellowthroat's status as endangered, its limited range, and the lack of a robust evaluation of its population (Rodríguez-Estrella et al. 1999, Escalante 2000, BirdLife International 2016) call for updated and precise assessments in areas where the population is concentrated, as at San Ignacio (Erickson et al. 2008). Such estimates are essential to effective management toward the species' conservation. Hence, our objective was to assess the abundance of the Belding's Yellowthroat at the oasis of San Ignacio during the species' reproductive season (from March to June, Bent 1953) and to generate more information on the species' ability to disperse.

\section{MATERIALS AND METHODS}

\section{Study Area}

The San Ignacio oasis $\left(27^{\circ} 17^{\prime} 55^{\prime \prime} \mathrm{N}, 112^{\circ} 53^{\prime} 35^{\prime \prime} \mathrm{W}\right.$; Figure 1$)$ is located less than $2 \mathrm{~km}$ from the town of San Ignacio, at the center of the Baja California Peninsula, an area that encompasses a diversity of ecosystems. San Ignacio is the main oasis in the area, and the largest on the peninsula, with a total surface of 269 ha (Maya et al. 1997). The water level in the oasis fluctuates only slightly, and the substrate varies from boulders to sand (Ruíz-Campos et al. 2014). The vegetation is mostly riparian abutted by xeric scrubland, interspersed with opportunistic exotic species (Ruíz-Campos et al. 2014).

\section{Field Work}

We visited the San Ignacio oasis from 29 May to 4 June ("May") and from 28 June to 4 July ("June") 2016. During both periods, we made point counts around the whole periphery of the oasis, starting at 07:00 and ending 

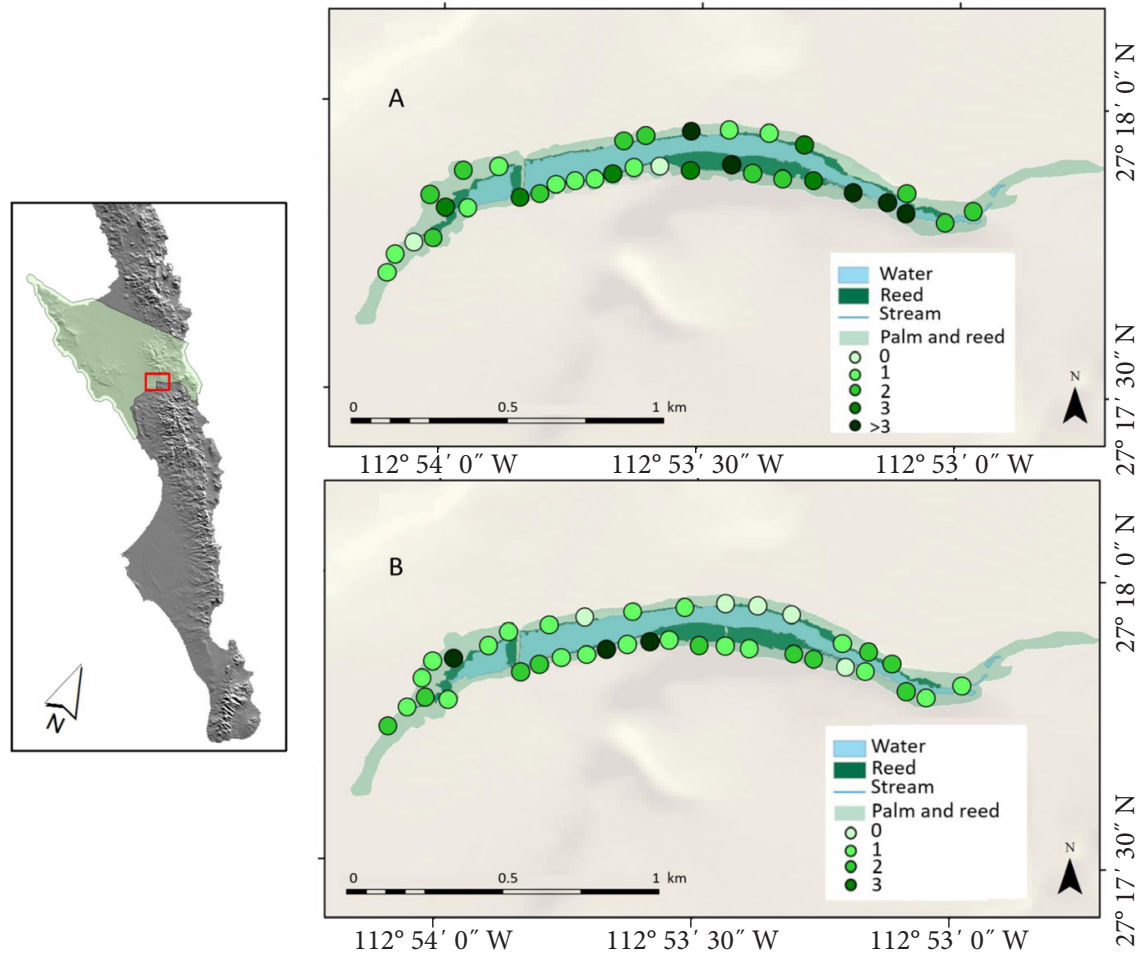

FIgURE 1. San Ignacio oasis, showing the habitat suitable for Belding's Yellowthroat and the count points. The color of the circles is scaled to the number of birds observed during silent counts. A, survey 29 May-4 June 2016; B, survey 28 June-4 July 2016.

at 11:00. We counted within a radius of $25 \mathrm{~m}$ of each point, and points were separated by at least $50 \mathrm{~m}$. In May, we counted from 34 points, in June from 37 . Between the two survey periods, 26 of the points coincided, and $80 \%$ of the area covered by the points overlapped. At each point, we counted in silence for 5 minutes and recorded the distance to each Belding's Yellowthroat detected ("silent counts"). For birds seen we measured the distance with a laser rangefinder, but for birds heard only we had to estimate the distance. We followed this silent count immediately by 10-minute "call counts", during which we broadcast calls and songs of the target species to attract birds. Because the points were situated at the edges of reedbeds, each $25-\mathrm{m}$ radius encompassed about 50\% prime habitat (reed and cattail) and 50\% suboptimal habitat (primarily palms). Also, the $25-\mathrm{m}$ radii surrounding the points did not cover the whole area of suitable habitat, so the counts represent a minimum estimate of abundance (Mikol 1980, Ralph et al. 1996). During both types of counts we recorded the sex and age (young or adult) of each individual seen according to its plumage (Dunn and Garrett 1997). We categorized birds that 
could not be observed carefully or that were only heard as undetermined. Also, we recorded the type of vegetation (cattail, reed, palm, or other) with which each bird (sighted or heard) was associated. In June we recorded whether the bird had been banded in May (see below).

The assumptions for both types of counts were those suggested by Wunderle (1994): (1) birds must be accurately identified, (2) sampling efforts must be adequate to detect the presence of the species, (3) differences among observers should be slight or accounted for, (4) differences in detectability among sites and months should be slight or accounted for.

Additionally, we captured Belding's Yellowthroats with mist nets $(12 \mathrm{~m}$ long $\times 2 \mathrm{~m}$ wide, $36-\mathrm{mm}$ mesh) placed adjacent to the oasis' water body. The capture effort consisted of 278 mist-net hours in May and 279 mist-net hours in June. During the first field trip (May), we determined the sex and age of each bird we captured, and applied unique combinations of colored bands to the tibia and tarsus of each bird. During the second field trip (June) we recorded whether each bird captured had been banded in May as well as its sex and age.

\section{Analysis}

We estimated the density and abundance of Belding's Yellowthroat at the San Ignacio oasis by three approaches: analyzing the results of the silent counts with the program Distance 7.3 (Thomas et al. 2010), extrapolating minimal abundance (as based on the call counts), and mark-recapture methods.

Distance Sampling. Distance 7.3 incorporates the distance of the observer to the bird to evaluate the probability of detection as a function of distance, from which it generates density estimates. The procedure is efficient and has delivered satisfactory results in studies of cryptic bird species like Belding's Yellowthroat (Rajpar and Zakaria 2010). Therefore, we recorded the distance to each bird found from the corresponding count point. The key function for estimating the abundance was half-normal, because of the high value of Akaike's information criterion (AIC) obtained and the decrease in the coefficient of variation compared to other functions (Thomas et al. 2010).

The assumptions for analysis with Distance 7.3 are that (1) the birds at the center point will always be detected, (2) the density is not affected by the presence or activities of the observers, and (3) the distance to each bird was measured accurately.

To estimate the total area (ha) of habitat (cattail and reed patches) suitable for Belding's Yellowthroat at San Ignacio, we examined Google Earth images. We corrected the area of suitable habitat with field data on the distribution of cattail and reed patches, as palm groves impede their detection by satellite photography. Then we multiplied density estimates obtained with the software Distance (average, maximum, and minimum) by the area of suitable habitat for the species to calculate an abundance estimate.

Extrapolation from Numbers Observed. We also obtained an approximation of the population size by extrapolating the minimum abundance of the species during the call counts. To do this, we divided the number of birds found by the total area covered in these counts, then multiplied by the total habitat available for the Belding's Yellowthroat at the oasis.

The assumptions for the use of the data from calling counts to estimate 
density were: (1) the observers' activities at one point do not affect the results of counts at the other points and (2) the birds counted were originally in the count circle in which they were detected.

Mark-Resighting Data. Finally, we obtained a third abundance estimation with the Chapman estimator $(N)$, developed for use with mark-recapture data. With the numbers of birds banded during May $(T)$, and resighted during call counts in June $(R)$, we applied the equation $N=[(C+1)(T+1) /(R$ $+1)$ ] -1 , where $C$ is the total number of individuals observed in June (Brittain and Böhning 2009). Only one individual banded in May was actually recaptured in June.

The assumptions for the analysis of the population size with the Chapman estimator are that (1) all birds banded in May were potentially observable in June and that (2) the number of birds resighted and counted in June represented a proportion of the total population similar to that of the birds banded in May.

Population Structure by Age/Sex Class. To assess the population structure, we compared the numbers recorded during the silent counts and the numbers captured. We categorized these numbers by three attributes: the month (May or June), the method (silent count or capture), and the birds' sex and age class (adult male, adult female, or juvenile). Then we used a $\chi^{2}$ test for multiple samples to determine whether the three classification criteria were independent (Zar 2010). Additionally, we carried out three $\chi^{2}$ tests of partial independence (Zar 2010) to evaluate whether (1) the frequencies of the group depended on the combined effect of the method and month, (2) the frequencies per month depended on the combination of method and group, and (3) the frequencies per method depended on the combination of the month and group ( $\alpha=0.05$, in all cases).

\section{RESULTS}

We detected 78 Belding's Yellowthroats during silent counts in May but only 51 in June. In contrast, during call counts we detected 103 birds in May and 98 in June.

We estimate the extent of habitat suitable for the Belding's Yellowthroat in the San Ignacio oasis at 14.95 ha. Corroboration in the field was important to avoid an underestimation of this area because at several points the palm trees screened cattails and reeds in satellite images.

Using the silent-count data, the software Distance calculated an effective detection radius between 13 and $21 \mathrm{~m}$ and an average population density between 16 and 18 birds/ha in both May and June (Table 1). From these average densities we estimate a total population of 271 birds during May and 240 birds during June (Table 1). Therefore, according to distance sampling, the population of Belding's Yellowthroat at the San Ignacio oasis is close to 250 (Table 1).

Those estimates are slightly greater than those obtained by extrapolation of the birds' density from call counts: 231 and 202 birds during May and June, respectively (Table 1). Finally, the population according to the Chapman estimator was similar: 260 birds (of 14 birds banded during May, 4 were resighted during June, Table 1 ).

The $\chi^{2}$ test indicated that the three classification criteria (age/sex class, 
TABLE 1 Radius of Detection, Density, and Abundance of Belding's Yellowthroat at San Ignacio by Three Methods

\begin{tabular}{|c|c|c|c|c|c|}
\hline \multirow[b]{2}{*}{ Month of survey } & \multicolumn{2}{|c|}{ Distance sampling } & \multicolumn{2}{|c|}{$\begin{array}{l}\text { Abundance } \\
\text { extrapolation }\end{array}$} & \multirow{2}{*}{$\begin{array}{c}\begin{array}{c}\text { Mark- } \\
\text { resighting }\end{array} \\
\text { June }\end{array}$} \\
\hline & May & June & May & June & \\
\hline Detection radius $(\mathrm{m})$ & 20.06 & 13.46 & $\mathrm{NA}^{a}$ & NA & NA \\
\hline Average density (birds/ha) & 18.16 & 16.05 & 15.28 & 13.49 & 20.13 \\
\hline Density upper limit ${ }^{b}$ (birds/ha) & 25.82 & 24.15 & 19.92 & 16.49 & NA \\
\hline Density lower limit ${ }^{b}$ (birds/ha) & 12.76 & 10.67 & 10.93 & 10.49 & NA \\
\hline Estimated abundance & 271 & 240 & 231 & 202 & 301 \\
\hline Abundance upper limit ${ }^{b}$ & 386 & 361 & 298 & 246 & NA \\
\hline Abundance lower limit ${ }^{b}$ & 191 & 160 & 163 & 157 & NA \\
\hline
\end{tabular}

${ }^{a} \mathrm{NA}$, not applicable.

${ }^{b}$ Upper and lower values of $95 \%$ confidence interval.

TABLE 2 Population Structure of Belding's Yellowthroat at San Ignacio by Two Methods in Each Month of Sampling ${ }^{a}$

\begin{tabular}{lccccc}
\hline & \multicolumn{2}{c}{ Silent counts } & & \multicolumn{2}{c}{ Captures } \\
\cline { 2 - 3 } \cline { 5 - 6 } & May & June & & May & June \\
\hline Males & $8(61.5)$ & $3(33.3)$ & & $12(75.0)$ & $3(25.0)$ \\
Females & $5(38.5)$ & $3(33.3)$ & & $3(18.7)$ & $2(16.7)$ \\
Juveniles & 0 & $3(33.3)$ & & $1(6.3)$ & $7(58.3)$ \\
Unidentified & 65 & 42 & & & \\
Total & 13 & 9 & & 16 & 12 \\
\hline
\end{tabular}

${ }^{a}$ Number of birds recorded, with percentage in parentheses.

month, and method) were interdependent $\left(\chi^{2} 7=18.41, p=0.01\right)$. The tests of partial independence revealed that the frequency by age/sex class was dependent on the combination of method and month $\left(\chi_{6}^{2}=18.21, p<0.01\right)$. Similarly, the frequency of records per month was dependent on the combination of age/sex class and method $\left(\chi^{2}{ }_{5}=14.97, p=0.01\right)$. In contrast, the frequency by method was independent of the combination of month and age/ sex class $\left(\chi^{2}{ }_{5}=3.42, p=0.63\right)$, which we interpret as implying that the silent counts and mist-netting yielded equivalent results. These tests also imply that between May and June the population structure changed, as a result of the incorporation of juveniles and a decrease in the frequency of adult males.

\section{DISCUSSION}

The number of Belding's Yellowthroats found during call counts, 98 to 103, represents a minimum value, since only $32 \%$ of the species' suitable habitat (cattail and reed) was surveyed. It is noteworthy that the total abundance extrapolated from this method is close to those the estimates generated by the other methods based on more rigorous principles, provided that the methods' assumptions are met. Our results, however, suggest that assumption 4 of distance sampling was not fully met: the difference in detectability by month may have been significant. 
Both the number of birds detected and the apparent density decreased from May to June (Table 1). But the radius of detection decreased, implying the birds became more difficult to detect. This may have been due to a change in the males' behavior, but if so that change in behavior affected the probability that an adult male would be captured as well as the probability that it would be observed. Another possibility is that some adult males dispersed away from the area. In June the juveniles began to appear, but these, being less conspicuous, were reflected in a small proportion in the counts.

Our estimates of the density of Belding's Yellowthroat at San Ignacio oasis ( 20 birds/ha) are much higher than those found at two locations farther south in Baja California Sur where the species' density has been assessed: San José del Cabo (23 $\left.03^{\prime} 05^{\prime \prime} \mathrm{N}, 109^{\circ} 41^{\prime} 17^{\prime \prime} \mathrm{W}\right)$ with 3.38-4.77 birds/ha, and Santiago $\left(23^{\circ} 29^{\prime} 13^{\prime \prime} \mathrm{N}, 109^{\circ} 43^{\prime} 03^{\prime \prime} \mathrm{W}\right.$ ) with 6.19 birds/ha (E. Palacios and D. Galindo in litt.). Four plausible reasons may explain these marked differences:

(1) The densities obtained by Palacios and Galindo (in litt.) are underestimates, as they were calculated from counts of adults only, while ours at the San Ignacio oasis were assessed from counts of young and adult birds. However, during May, when only adults were present and counted at San Ignacio oasis, densities estimated there were still much higher than those reported by Palacios and Galindo (in litt.).

(2) Those researchers obtained their data from fixed-radius point counts (not considering the distance to each bird), a method prone to underestimating bird densities because it overlooks the fact that that the probability of detecting a bird diminishes as the distance between the bird and the observer increases (Buckland et al. 1993, Whitworth et al. 2007).

(3) Also with respect to detectability, the fixed 45 - $m$ radius used by Palacios and Galindo (in litt.) appears to be too great for a species as cryptic as Belding's Yellowthroat. Ralph et al. (1996) recommended a radius of $25 \mathrm{~m}$ for such species.

(4) Finally, the possibility that the oasis of San Ignacio offers better habitat for Belding's Yellowthroat cannot be ruled out, because both San José del Cabo and Santiago are surrounded by human settlements.

Oases harbor a greater number of organisms than do adjacent arid areas (Rodríguez-Estrella et al. 1997), and in the oases of Baja California Sur the maximum density of all species of birds combined reaches nearly $20 \mathrm{birds} / \mathrm{ha}$ (Carmona et al. 2005). In the central section of the peninsula few other species use cattail and reed habitats during the breeding season (Bancroft 1930), so it is plausible for this habitat to support 20 Belding's Yellowthroats/ha.

There is one previous estimate of the population of Belding's Yellowthroat at the San Ignacio oasis (537-648 birds, BirdLife International 2016). However, there is a conceptual problem with this estimate, since it was obtained by extrapolating a descriptor of abundance measured in birds/hour (RodríguezEstrella et al. 1999) to the total area of the oasis, as if it were a density descriptor (BirdLife International 2016). In this way, Belding's Yellowthroat's abundance at four peninsular oases was calculated, and from there the species' current total population size was extrapolated. Therefore, the estimates by BirdLife International (2016) for San Ignacio and the other four peninsular oases should be improved and updated. On the basis of current data, we cannot say whether the apparent decrease from 1994-1996 to 2016 represents an actual change. 
In such context, the coincidence among the abundances we estimated by three different techniques (Table 1) suggests that the estimates' accuracy is adequate. The convergence encourages us to recommend an update of estimates of the Belding's Yellowthroat population elsewhere, following standardized methods like those we report here.

The decrease in males (in both abundance and proportion) detected between May and June was possibly due to their dispersal from the oasis, while the females stay longer. Early post-breeding dispersal of the adults has been recorded in other species with specialized dietary requirements, like the Magnificent Frigatebird (Fregata magnificens, Moreno and Carmona 1988) and is interpreted as an adaptation for reducing competition for food. In accordance with the concept of such dispersal, adult Belding's Yellowthroats of both sexes have been seen in the nonbreeding season away from the species' breeding areas, three males (Erickson et al. 2008) and two females (pers. obs.). This evidence suggests that the species can disperse, so if a population of Belding's Yellowthroats is eradicated by a catastrophe the site could be recolonized if the suitable conditions regenerate.

In summary, the San Ignacio oasis currently supports a population of approximately 250 Belding's Yellowthroats. Because of the apparent decrease in the number of males from May to June, it is plausible that some adults disperse to other areas after the reproductive season (between June and July), as has been observed in some other species.

\section{ACKNOWLEDGMENTS}

We thank the staff of the Vizcaíno Biosphere Reserve: Everardo Mariano, Celerino Montes, and Ramón Zúñiga, for their unconditional support. Thank you to Espacios Naturales y Desarrollo Sustentable A.C., especially to Verónica Salas for her administrative help and to Betsy Martínez, Jorge Guzmán, Leonardo Vázquez, and Abril Santoyo for their help in the field work. Thank you to Daniel Ruthrauff, Lori Hargrove, and Philip Unitt for their reviews of the manuscript.

\section{LITERATURE CITED}

Bancroft, G. 1930. The breeding birds of central Lower California. Condor 32:20-49; doi $10.2307 / 1363635$.

Bent, A. C. 1953. Life histories of North American wood warblers. U.S. Natl. Mus. Bull 203; doi 10.5479/si.03629236.203.1.

BirdLife International. 2016. Species factsheet: Geothlypis beldingi, in The IUCN Red List of Threatened Species 2016; www.iucnredlist.org/species/ $22721839 / 118502506$.

Brittain, S., and D. Böhning. 2009. Estimators in capture-recapture studies with two sources. Adv. Stat. Analysis 93:23-47; doi 10.1007/s10182-008-0085-y.

Buckland, S. T., Anderson, D. R., Burnham, K. P., and Laake, J. L. 1993. Distance Sampling: Estimating Abundance of Biological Populations. Chapman and Hall, London; doi 10.1007/978-94-011-1572-8.

Carmona, R., Ruiz-Campos, G., Castillo-Guerrero, J. A., and Brabata, G. 2005. Patterns of occurrence and abundance of land birds on Espíritu Santo Island, Gulf of California, México. Southwest. Nat. 50:440-447; doi 10.1894/0038-4909(2005)050[0440:POOAAO]2.0.CO;2.

Dunn, J. L., and Garrett, K. L. 1997. A Field Guide to Warblers of North America. Houghton Mifflin, Boston. 
Erickson, R. A., Hamilton, R. A., and Mlodinow, S. G. 2008. Status review of Belding's Yellowthroat Geothlypis beldingi, and implications for its conservation. Bird Cons. Int. 18:219-228; doi 10.1017/S0959270908000221.

Escalante, P. 2000. Mascarita peninsular (Geothlypis beldingi), in Las Aves de México en Peligro de Extinción (G. Ceballos and L. V. Márquez, eds.), pp. 304-305. CONABIO-Instituto de Ecología-Fondo de Cultura Económica, Mexico City.

Maya, Y., Coria, R., and Dominguez, R. 1997. Características de los oasis, in Los Oasis de la Península de Baja California (L. Arriaga and R. Rodríguez-Estrella, eds.), pp. 5-26. SIMAC-CIB, La Paz, Mexico.

Mikol, S. A. 1980. Field guidelines for using transects to sample nongame bird populations. FWS/OBS-80/58, U.S. Fish and Wildlife Service, Biological Services Program, Washington, DC.

Moreno M., L. A., and Carmona P., L. R. 1988. Ecología reproductiva de Fregata magnificens en isla Santa Margarita, B. C. S. Bachelor thesis, Universidad Autónoma de Baja California Sur, La Paz, México.

Rajpar, M. N., and Zakaria, M. 2010. Density and diversity of water birds and terrestrial birds at Paya Indah Wetland Reserve, Selangor Peninsular Malaysia. J. Biol. Sci. 10:658-666; doi doi.org/10.3923/jbs.2010.658.666.

Ralph, C. J., Geupel, G. R., Pyle, P., Martin, T. E., DeSante, D. F., and Milá, B. 1996. Manual de métodos de campo para el monitoreo de aves terrestres. Gen. Tech. Rep. PSW-GTR-159, Pacific Southwest Res. Sta., U.S. Forest Service, Berkeley, CA; doi 10.2737/PSW-GTR-159.

Rodríguez-Estrella, R., Rubio, R. L., and Pineda, E. 1997. Los oasis como parches atractivos para las aves terrestres residentes e invernantes, in Los Oasis de la Península de Baja California (L. Arriaga and R. Rodríguez-Estrella, eds.), pp. 157-195. SIMAC-CIB, La Paz, Mexico.

Rodríguez-Estrella, R., Delgado, L. R., Pineda, E., and Blanco, G. 1999. Belding's Yellowthroat: Current status, habitat preferences and threats in oases of Baja California, Mexico. Anim. Cons. 2:77-84; doi 10.1111/j.1469-1795.1999.tb00052.x.

Ruíz-Campos, G., Andreu-Soler, A., Vidal-Abarca, M. R., Delgadillo-Rodríguez, J., Suárez A., M. L., González-Abraham, C., and Luja, V. H. 2014. Catálogo de Humedales Dulceacuícolas de Baja California Sur, México. INECC-SEMARNAT, Mexico City.

SEMARNAT. 2010. Norma Oficial Mexicana NOM-059-SEMARNAT-2010. Diario Oficial de la Federación, 30 diciembre, segunda sección.

Stith, B. M., Fitzpatrick, J. W., Woolfenden, G. E., and Pranty, B. 1996. Classification and conservation of metapopulations: A case study of the Florida Scrub-Jay, in Metapopulations and Wildlife Conservation (D. R. McCullough, ed.), pp. 187-215. Island Press, Washington, DC.

Thomas, L., Buckland, S. T., Rexstad, E. A., Laake, J. L., Stringber, S., Hedley, S. L., Bishop, J. R. B., Marques, T. A., and Burnham, K. P. 2010. Distance software: Design and analysis of distance sampling surveys for estimating population size. J. Appl. Ecol. 47:5-14; doi 10.1111/j.1365-2664.2009.01737.x.

Whitworth, D., Newman, S. H., Mundkur, T., and Harris, P. 2007. Wild birds and avian influenza: An introduction to applied field research and disease sampling techniques. FAO Animal Production and Health Manual 5. Food and Agriculture Organization of the United Nations, Rome; www.fao.org/3/a1521e/a1521e.pdf.

Wunderle, J. M. 1994. Census methods for Caribbean land birds. Gen.. Tech. Rep. SO-98, Southern Forest Exp. Sta., U.S. Forest Service, New Orleans; doi 10.2737/ SO-GTR-98.

Zar, J. H. 2010. Biostatistical Analysis, $5^{\text {th }}$ ed. Prentice Hall, Upper Saddle River, NJ. 